\title{
State of art of oral vitamin B12 (cobalamin) treatment in Biermer's disease (pernicious anemia)
}

\author{
Emmanuel Andrès ${ }^{1 *}$, Abrar-Ahmad Zulfiqar², Thomas Vogel ${ }^{3}$ and Georges Kaltenbach ${ }^{3}$ \\ ${ }^{1}$ Department of Internal Medicine, Diabetes and Metabolic Diseases, Hôpitaux Universitaires de Strasbourg, Strasbourg, France \\ ${ }^{2}$ Department of Geriatrics, CHRU de Rouen, Rouen, France \\ ${ }^{3}$ Department of Geriatrics and Internal Medicine Universitaires de Strasbourg, Strasbourg, France
}

\begin{abstract}
In the setting of vitamin B12 (cobalamin) deficiency, new routes (oral and nasal) of vitamin B12 replacement have being developed and studied. In Biermer's disease, two prospective controlled randomized studies, a recent systematic review by the Cochrane group and four prospective studies were found and provide evidence that oral vitamin B12 treatment may adequately treat cobalamin deficiency. The efficacy was documented with a marked improvement in serum vitamin B12 levels or normalization of this latter. The clinical efficacy was also established with an improvement or a normalization of hematological parameters. The safety was documented in the majority of the studies. In this setting, oral replacement will be of interest for clinicians to avoid painful and administration difficulties, and cost of monthly injections. To date, effect of oral vitamin B12 treatment has not yet been adequately documented in patients presenting with severe neurological manifestations.
\end{abstract}

\section{Introduction}

Vitamin B12 (cobalamin) is the largest and most complex of all the vitamins [1]. Their molecular structure is $\mathrm{C}_{63} \mathrm{H}_{88} \mathrm{CoN}_{14} \mathrm{O}_{14} \mathrm{P}$ or $\mathrm{C}_{62} \mathrm{H}_{88} \mathrm{CoN}_{13} \mathrm{O}_{14} \mathrm{P}$ and their molecular weight is $1329.37 \mathrm{~g} / \mathrm{mol}$ (Figure $1)$. The name vitamin $\mathrm{B} 12$ is generic for a specific group of cobaltcontaining corrinoids with several essential biological activities in humans. Interestingly it is the only known metabolite to contain cobalt, which gives this water-soluble vitamin its red color. This group of corrinoids is also known as cobalamins.

The main cobalamins in humans and animals are hydroxo-, adenosyl- and methyl- cobalamin, the last two being the active coenzyme forms [2]. In fact, these compounds are necessary for hematopoiesis, neural metabolism, DNA and RNA production, and carbohydrate, fat, and protein metabolism.

To date, management of vitamin B12 deficiency with vitamin B12 injections is currently well established, but new routes of vitamin B12 administration, particularly oral and nasal, are being studied $[3,4]$. The treatment is based on cyano- and hydroxo-cobalamin in the form of tablets, injectable or oral solutions.

This narrative review summarizes the current knowledge on the efficacy and safety of oral vitamin B12 (cobalamin) treatment (replacement) in Biermer's disease (pernicious anemia).

\section{References search}

A literature search was performed on the PubMed database of the US National Library of Medicine and on Scholar Google. We searched for articles published between January 2010 and June 2018, using the following key words or associations: "vitamin B12", "cobalamin", "vitamin B12 deficiency", "cobalamin deficiency", "oral vitamin B12", "oral cobalamin", "oral vitamin B12 therapy", "oral cobalamin therapy", "Biermer's disease", "pernicious anemia”; restrictions included: Englishor French-language publications; published from January 1, 2010, to July 1, 2018; human subjects; clinical trials, review articles or guidelines.

Additional studies were obtained from references of identified studies, the Cochrane Library and the ISI Web of Knowledge. Data gleaned from international meetings were also used, as information gleaned from commercial sites on the web.

All of the English and French abstracts were reviewed by at least 2 senior researchers from our research team (CAREnce en vitamine $B 12$ [CARE B12], in the University Hospital of Strasbourg, Strasbourg, France). After rigorous selection, only 37 papers were selected and analyzed. The latter were used to write this paper in the form of a narrative review.

\section{Cobalamin metabolism and its abnormalities or defects}

Cobalamin metabolism is complex and is made up of many processes, abnormalities or defects in any one of which can lead to vitamin B12 deficiency [1]. The different stages of cobalamin metabolism and corresponding causes of cobalamin deficiency are shown in Figure 1 [4,5]. In this setting, the best-known pathology is Biermer's disease also classically know as pernicious anemia.

Biermer's disease is an autoimmune gastritis resulting from the destruction of gastric parietal cells and consequent impairment of

*Correspondence to: $\mathrm{E}$ Andrès, Service de Médecine Interne, Diabète et Maladies Métaboliques, Clinique Médicale B, Hôpital Civil - Hôpitaux Universitaires de Strasbourg, 1 porte del'Hôpital, 67091 Strasbourg Cedex, France, Tel: 33388115066; Fax: 33388116262; E-mail: Emmanuel.ANDRES@chru-strasbourg.fr

Key words: vitamin B12, cobalamin, oral vitamin B12, oral cobalamin, cobalamin deficiency, Biermer's disease, Pernicious anemia, treatment, therapy

Received: August 13, 2018; Accepted: September 04, 2018; Published: September 07, 2018 


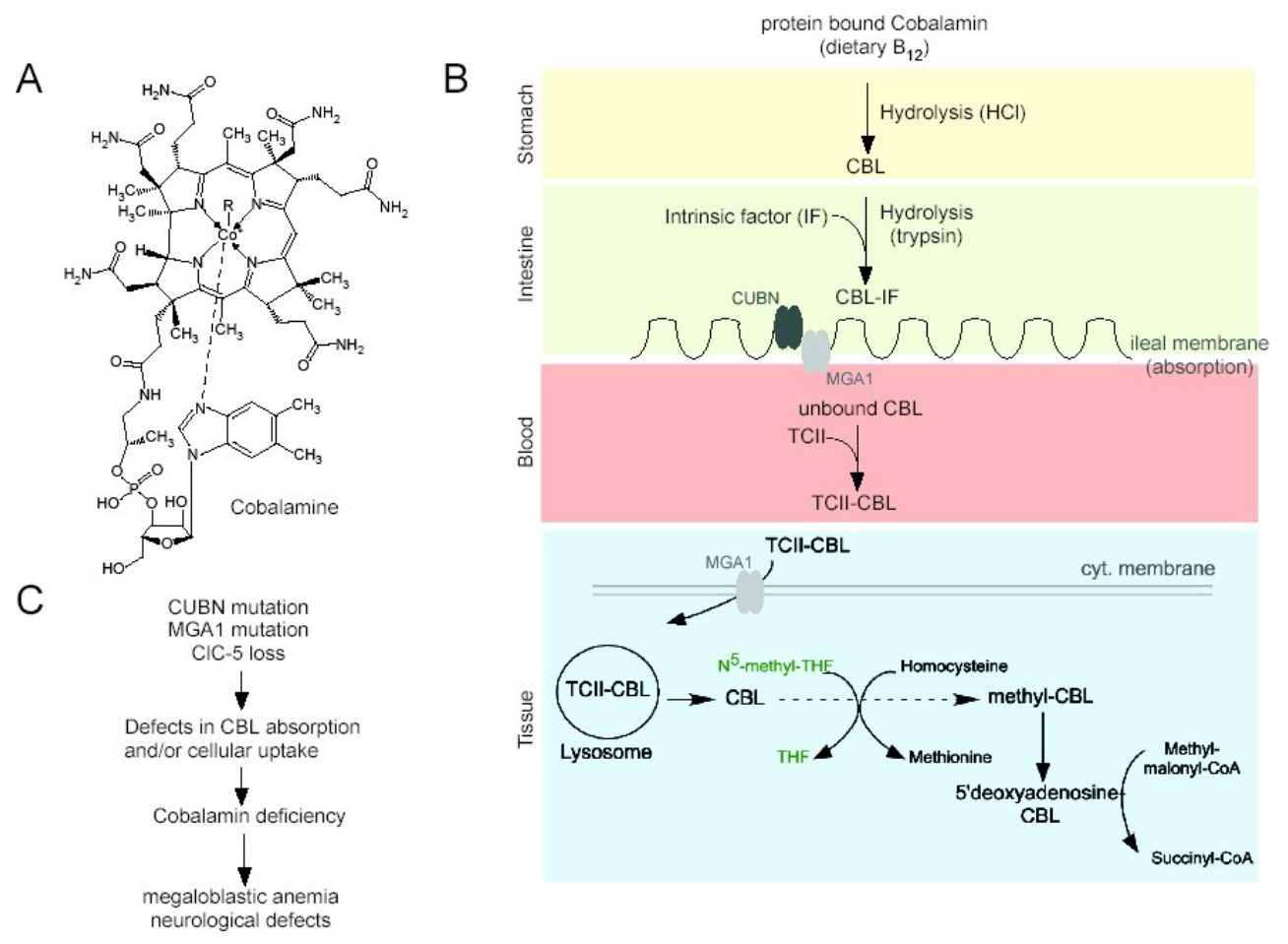

Figure 1. Structure (A) and metabolism of the vitamin B12 (B). The metabolic journey of cobalamin (cbl) from nutrient intake to its intestinal absorption. Endocytic receptors and proteins responsible for vitamin B12 intestinal absorption include cubilin (CUBN), amnionless (AMN), receptor-associated protein and megalin (MGA1). The membrane megalin/transcobalamin II (TCII)-receptor complex allows the cellular uptake of cbl. Lysosomal-mediated degradation of TCII and subsequent release of free-cbl is essential for vitamin B12 metabolic functions. MS, methonine synthase; THF, tetrahydrofolate; MTHFR, methylene tetrahydrofolate reductase; MCM, methylmalonyl CoA mutase [1,5]

intrinsic factors secretion to bind the ingested vitamin B12 [4,5]. In this setting, other autoimmune disorders are commonly associated as: thyroid disease (mainly Hashimoto's disease), Sjögren's syndrome, type 1 diabetes mellitus, vitiligo, even coeliac disease.

A typical Western diet contributes 3-30 $\mu$ g of vitamin B12 per day towards the recommended dietary allowance of $2.4 \mu \mathrm{g}$ par day for adults [5]. The 5-10-year delay between the onset of vitamin B12 deficiency and the development of clinical symptoms is directly attributable to hepatic stores of cobalamin (>1.5 mg) and the enterohepatic cycle [4,5].

In the context of this paper, it is important to know that between $1-5 \%$ of "free" cobalamin or "crystalline" cobalamin is absorbed by passive diffusion along the entire gastro-intestinal tract, from the oral or nasal mucosa to the colic mucosa [4,5]. Passive diffusion accounts for about $1 \%$ of total absorption, and this route of absorption is unaffected in patients with pernicious anemia. This absorption explains the mechanism underlying oral and nasal treatment of vitamin B12 deficiencies.

In humans, cobalamin participates in 2 enzymatic processes (Figure 1) [6]. First in the methionine synthase reaction, homocysteine is converted to methionine allowing for the "recycling" of 5-methyltetrahydrofolate (THF) to N5,10 methylene-THF which is needed for the de novo synthesis of thymidylic acid and ultimately, for DNA formation. Thus, homocysteine accumulates, methionine and in term S-adenosylmethionine decrease. This later limits N5,10-methyleneTHF formation by decreasing the synthesis of formyl-THF. These modifications may limit many methylation reactions, including reactions involving DNA and myelin basic protein. Second in the methylmalonyl CoA mutase reaction, methylmalonyl $\mathrm{CoA}$, derived from propionic acid synthesized by intestinal bacteria, is converted to succinyl CoA, a precursor for fatty acid and heme synthesis. Thus, cobalamin deficiency results in methylmalonic acid (MMA) accumulation.
These reactions explain the main clinical manifestation of vitamin B12 deficiency: megaloblastic anemia and neuro-cognitive abnormalities [1,2]. They also explain the elements of the definition of vitamin B12 deficiency. Thus, vitamin B12 deficiency is characterized by serum vitamin $\mathrm{B} 12$ levels $<150 \mathrm{pmol} / \mathrm{L}(200 \mathrm{pg} / \mathrm{mL}) \pm$ serum total homocysteine levels $>13 \mu \mathrm{mol} / \mathrm{L}$ or urinary MMA $>0.4 \mu \mathrm{mol} / \mathrm{L}$ [7]

\section{Manifestations and etiologies of vitamin B12 deficiency in adults}

Vitamin B12 deficiency is relatively frequent in elderly patients, around 2 to more than $30 \%$ according to depending on the target population, the design and location of the studies, but is often unrecognized or not investigated because the clinical manifestations of vitamin B12 deficiency are subtle [5]. Absolute vitamin B12 deficiency (established in regard of the aforementioned definition of vitamin B12 deficiency, mainly associated with documented clinical manifestation) occurs of at least $6 \%$ of adults (at least 60 years-old) and elderly patients. In these populations, a marginal deficiency occurs in around $20 \%$ of elderly subjects. In practice for clinicians, it is important to note that certain complications of vitamin B12 deficiency, in particular psychoneurological and hematological complications are potentially serious, as seen in Table 1, and therefore require investigation in all patients who present with vitamin or nutritional deficiency.

In industrialized countries, disorders such as nutritional deficiencies, malabsorption or genetic cobalamin disorders are rare or exceptional etiologies of vitamin B12 deficiency, especially in adults [5]. In European countries, it has been estimated that the prevalence of Biermer's disease is approximately $4 \%$ of the population. Even outside the classic Biermer's disease, a more common problem is foodcobalamin malabsorption (FCM), a disorder characterized by the inability to release cobalamin from food or its binding proteins $[8,9]$. In 
Table 1. Main clinical features of vitamin B12 (cobalamin) deficiency $[1,2,5]$

\begin{tabular}{|c|c|c|c|}
\hline Hematological manifestations & Neuro-psychiatric manifestations & Digestive manifestations & Other manifestations \\
\hline $\begin{array}{l}\text { Frequent: macrocytosis, neutrophil } \\
\text { hypersegmentation, aregenerative } \\
\text { macrocytary anemia, medullar } \\
\text { megaloblastosis ("blue spinal cord") } \\
\text { Rare: isolated thrombocytopenia and } \\
\text { neutropenia, pancytopenia } \\
\text { Very rare: hemolytic anemia, thrombotic } \\
\text { microangiopathy (presence of schistocytes) }\end{array}$ & $\begin{array}{l}\text { Frequent: polyneuritis (especially sensitive), } \\
\text { ataxia, Babinski's phenomenon } \\
\text { Classic: combined sclerosis of the spinal cord } \\
\text { Rare: cerebellar syndromes affecting the } \\
\text { cranial nerves including optic neuritis, optic } \\
\text { atrophy, urinary and/or fecal incontinence } \\
\text { Under study: changes in the higher functions, } \\
\text { dementia, stroke and atherosclerosis } \\
\text { (hyperhomocysteinemia), parkinsonian } \\
\text { syndromes, depression, multiple sclerosis }\end{array}$ & $\begin{array}{l}\text { Classic: Hunter's glossitis, jaundice, LDH } \\
\text { and bilirubin elevation ("intramedullary } \\
\text { destruction") } \\
\text { Debatable: abdominal pain, dyspepsia, } \\
\text { nausea, vomiting, diarrhea, disturbances in } \\
\text { intestinal functioning } \\
\text { Rare: } \text { resistant and recurring mucocutaneous } \\
\text { ulcers }\end{array}$ & $\begin{array}{l}\text { Frequent: tiredness, loss of appetite } \\
\text { Under study: atrophy of the vaginal } \\
\text { mucosa and chronic vaginal and } \\
\text { urinary infections (especially mycosis), } \\
\text { hypofertility and repeated miscarriages, } \\
\text { venous thromboembolic disease, angina } \\
\text { (hyperhomocysteinemia) }\end{array}$ \\
\hline
\end{tabular}

several recent studies, FCM and Biermer's disease are the main causes of vitamin B12 deficiency in adults and elderlies (between 70 to $80 \%$ ) [9].

In this relatively recent description syndrome of FCM, at least in its complete form, the absorption of unbound ("free" or crystalline) cobalamin remains normal (Figure 1) [8]. This maldigestion produces a more slowly progressive and long-term partial depletion of vitamin B12 stores. In comparison, Biermer's disease leads to a more rapid and complete depletion of the cobalamin store, engendered by disruption of intrinsic-factor-mediated absorption $[8,9]$. This may explain the subtle manifestations of the FCM in some patient, especially in the early stages.

The partial nature of this form of malabsorption (bound-cobalamin) explains that oral vitamin B12 may be effective to cure the deficiency. This also explains why the required treatment dose of oral vitamin B12 may be lower in FCM than in Biermer's disease [10].

\section{Parenteral vitamin B12 treatment}

The classic treatment for vitamin B12 deficiency is by parenteral administration, as intramuscular (IM) injections in main countries, in the form of cyano- and, more rarely, hydroxyl- (also called hydroxo-) or methyl-cobalamin, especially for this later for the treatment of genetic deficiencies $[10,11]$.

This mode of administration is explained by the fact that the 2 main etiologies of vitamin B12 deficiencies were historically the pernicious anemia and the malabsorption, in particular following gastrectomy for stomach ulcer [11]. Theoretically, hydroxocobalamin have several advantages due to better tissue retention and storage as demonstrated in some studies [12]. To our knowledge, it does seem not so evident in clinical practice.

However, despite ancient use, the management concerning both the dose and schedule of administration varies considerably between countries [10]. This fact is related to the lack of randomized study fulfilled the criteria of evidence based-medicine in this field of medicine. In the USA and UK, doses ranging from 100 to $1,000 \mu \mathrm{g}(0.1$ to $1 \mathrm{mg})$ per month (or every 2-3 months when hydroxocobalamin is given) are used for the duration of the patient's life [11]. In France, treatment involves the administration of $1,000 \mu \mathrm{g}(1 \mathrm{mg})$ of cyanocobalamin per day for 1 week, followed by $1,000 \mu \mathrm{g}(1 \mathrm{mg})$ per week for $1 \mathrm{month}$, followed by $1,000 \mu \mathrm{g}(1 \mathrm{mg})$ per month, again, normally for the remainder of the patient's lifetime [10].

\section{Oral vitamin $B 12$ treatment}

Since cobalamin is absorbed by intrinsic factor-independent passive diffusion, daily high-dose (pharmacological dose, 1,000 to 2,000 $\mu \mathrm{g}$ [1 to $2 \mathrm{mg}$ ] per day) oral vitamin B12 (cyanocobalamin) can induce and maintain remission in patients with megaloblastic anemia $[3,13]$. In fact, as we have seen before, 1 to $5 \%$ of oral vitamin B12 is absorbed through passive way [4]. In this setting, alternative routes of cobalamin administration have been developed, experimented and used with good effect such as the oral $[3,10,13]$ and nasal $[14,15]$. These other routes of administration have been proposed as a way of avoiding the discomfort, inconvenience and cost of monthly injections (with the need of a nurse) $[16,17]$.

To our knowledge, several narrative reviews, including patients with Biermer's disease, have reported preliminary data of the efficacy of oral vitamin B12 treatment [3,10,18,19]. Although well done methodologically, results of these reviews have remained relatively confidential, without any real change in world practice at the beginning of the 2000's. This practice is however predominant in the Nordic countries. In these countries, curative oral vitamin B12 treatment accounts for more than $70 \%$ of the total vitamin B12 prescribed in Sweden since the 1980s [20].

Nevertheless, to date, with the dissemination of knowledge (through the $W e b$ ) and thanks to the existence of good quality studies, this is changing. Thus, at least four studies that fulfilled the criteria of evidence based-medicine (randomized study, systematic review) supported the efficacy of oral vitamin B12 therapy [21-24]. In the literature, several other recent not randomized studies support the efficacy or oral vitamin B12 replacement $[10,17]$.

\section{Randomized controlled studies of oral vitamin B12 therapy in vitamin $B 12$ deficiency}

Several prospective randomized controlled studies comparing oral vitamin B12 vs. IM vitamin B12 treatment have well-documented the efficacy (defined as the normalization and or a significant increase of the serum vitamin B12 level) and safety of oral vitamin B12 as a curative treatment $[20,21,24]$. Three of these currently published prospective studies include at least patients with potential Biermer's disease $(n=18)$. It is to note that the treatment regime of vitamin B12 (frequency and daily dose) the oral and IM groups varied in these studies. To our knowledge, only 2 of the randomized studies have welldocumented the efficacy of oral vitamin B12 therapy in term of serum vitamin B12 levels (Table 2) [21,22]. Moreover only 2 studies reported data on adverse events.

In a first study, Kuzminski et al. in a prospective randomized trial including 38 patients (7 with pernicious anemia [18,4\%]), have reported improvement of hematological parameters and vitamin B12 levels (mean value: $907 \mathrm{pg} / \mathrm{mL}$ ), after 4 months of oral cyanocobalamin replacement using a much higher dose (i.e. 2,000 $\mu \mathrm{g}$ [2 mg] per day) (Table 2) [21]. In this study, serum vitamin B12 levels were significantly higher in the oral $(2000 \mu \mathrm{g}$ [2 mg] of vitamin B12) compared with IM $(1000 \mu \mathrm{g}[1 \mathrm{mg}]$ of vitamin B12) group at 2 months: $643 \pm 328 v \mathrm{s.} 306 \pm$ $118 \mathrm{pg} / \mathrm{mL} ; p<0.001$. The difference was even greater at 4 months: 1005 \pm 595 vs. $325 \pm 165 \mathrm{pg} / \mathrm{mL}$. Four of the 18 patients in the oral group and 
Table 2. Prospective randomized controlled studies of oral vitamin B12 treatment in patients with vitamin B12 deficiency, including patients with Biermer's disease [21,22]

\begin{tabular}{|c|c|c|}
\hline Study characteristics (number of patients) & Therapeutic modalities & Results \\
\hline $\begin{array}{l}\text { Prospective randomized controlled study } \\
\mathrm{n}=38 \text {, including } 7 \text { patients with Biermer's } \\
\text { disease [21] }\end{array}$ & $\begin{array}{l}\text { Oral crystalline cyanocobalamin: } 2,000 \\
\mu \mathrm{g}(2 \mathrm{mg}) \text { per day, during at least } 4 \\
\text { months }\end{array}$ & $\begin{array}{l}\text { The mean pretreatment values for serum cobalamin, methylmalonic acid, and homocysteine were, } \\
\text { respectively, } 93 \mathrm{pg} / \mathrm{mL}, 3,850 \mathrm{nmol} / \mathrm{L} \text {, and } 37.2 \mu \mathrm{mol} / \mathrm{L} \text { in the oral group and } 95 \mathrm{pg} / \mathrm{mL}, 3,630 \\
\mathrm{nmol} / \mathrm{L} \text {, and } 40.0 \mu \mathrm{mol} / \mathrm{L} \text { in the parenteral therapy group. After } 4 \text { months of therapy, the respective } \\
\text { mean values were } 1,005 \mathrm{pg} / \mathrm{mL}, 169 \mathrm{nmol} / \mathrm{L} \text {, and } 10.6 \mu \mathrm{mol} / \mathrm{L} \text { in the oral group and } 325 \mathrm{pg} / \mathrm{mL} \text {, } \\
265 \mathrm{nmol} / \mathrm{L} \text {, and } 12.2 \mu \mathrm{mol} / \mathrm{L} \text { in the parenteral group (IM). The higher serum cobalamin and lower } \\
\text { serum methylmalonic acid levels at } 4 \text { months posttreatment in the oral group } v s \text {. the parenteral } \\
\text { group were significant, with } p<0.0005 \text { and } p<0.05 \text {, respectively } \\
\text { Correction of hematological and neurological abnormalities was prompt and indistinguishable } \\
\text { between the } 2 \text { groups }\end{array}$ \\
\hline $\begin{array}{l}\text { Prospective randomized open-label study, } \\
\mathrm{n}=60 \text {, including } 7 \text { patients with Biermer's } \\
\text { disease [22] }\end{array}$ & $\begin{array}{l}\text { Oral crystalline cyanocobalamin: at a } \\
\text { daily dose of } 1,000 \mu \mathrm{g}(1 \mathrm{mg}) \text { for } 10 \\
\text { days (oral group) or cobalamin IM: } \\
1,000 \mu \mathrm{g}(1 \mathrm{mg}) \text { once daily for } 10 \\
\text { days (IM group). After } 10 \text { days, both } \\
\text { treatments were administered once a } \\
\text { week for } 4 \text { weeks, and after that, once } \\
\text { a month for life }\end{array}$ & $\begin{array}{l}\text { The mean serum vitamin B12 concentration increased significantly from day } 0 \text { to } 90(p<0.001) \text {. } \\
\text { In the oral group, at days } 30 \text { and } 90 \text {, all hematological parameters changed significantly } v s \text {. day } 0 \\
\text { (mean hemoglobin levels increased [both } p<0.001 \text { ]; mean corpuscular volume decreased [both } \\
p<0.001 \text { ]; mean white blood cell count increased [day } 30, p<0.01 \text {; day } 90, p<0.001 \text {; ; and mean } \\
\text { platelet count increased [both } p<0.001 \text { ]). Reticulocytosis was observed in all patients. These } \\
\text { hematological parameters and the recovery patterns were similar between the } 2 \text { groups } \\
\text { Neurological improvement was detected in } 78 \% \text { in the oral group and } 75 \% \text { in the IM group at day } \\
30\end{array}$ \\
\hline
\end{tabular}

4 of the 15 in the IM group had a neurological response with a marked improvement or clearing of paresthesia, ataxia, or memory loss.

Bolaman et al. in a prospective randomized trial of 60 patients (11 with pernicious anemia [18,3\%]), also reported significant improvement of hematological parameters and vitamin B12 levels (mean improvement: $+140.9 \mathrm{pg} / \mathrm{mL}$ ), after 3 months of daily $1,000 \mu \mathrm{g}$ (1 mg) of oral cyanocobalamin therapy (Table 2) [22]. In this study, there was an increase in serum vitamin B12 levels in both groups (1000 $\mu \mathrm{g}$ [1 mg] of oral vitamin B12 vs. $1000 \mu \mathrm{g}$ [1 mg] of IM vitamin B12) at 90 days: $213.8 \mathrm{pg} / \mathrm{mL}$ in the oral and $225.5 \mathrm{pg} / \mathrm{mL}$ in the IM group. There was a statistically significant difference between days 0 and 90 in both groups $(p<0.0001)$, but authors did not analyze difference between both groups. Both groups reported improvements of cognitive functions, sensory neuropathy, and vibration sense, but there was no statistically significant difference between both groups.

In a recent controlled, randomized, multicenter, parallel, noninferiority clinical trial lasting one year, a preliminary analysis gives a glimpse that the oral route may be as effective and safety and more cheaply than the IM route [25]. This study involves 23 primary healthcare centers in the Madrid region (Spain), and 320 patients $\geq 65$ years of age. In this study, IM vitamin B12 will be administered as follows: $1,000 \mu \mathrm{g}(1 \mathrm{mg})$ on alternate days in weeks 1 and 2, $1,000 \mu \mathrm{g}$ (1 mg) per week in weeks 3-8, and 1,000 $\mu \mathrm{g}(1 \mathrm{mg})$ per month in weeks 9-52. In the oral arm, the vitamin B12 will be administered as: $1,000 \mu \mathrm{g}$ (1 mg) per day in weeks 1-8 and 1,000 $\mu \mathrm{g}(1 \mathrm{mg})$ per week in weeks 9-52. The definitive results of the Project OB12 study are expected for 2020.

In another randomized, parallel-group, double-blind, dose-finding trial, Eussen et al. showed that the lowest dose of oral cyanocobalamin required to normalize mild vitamin B12 deficiency is more than 200 times the recommended dietary allowance of approximately $3 \mu \mathrm{g}$ daily (i.e. $>500 \mu \mathrm{g}[0.5 \mathrm{mg}]$ per day) [24]. No data of the cobalamin deficiency etiology is available. Apart from helping to determine the dose, this study gives no indication for the Practitioners of the clinical effectiveness of oral vitamin B12 treatment.

It is to note that in the above studies explored the regression of the clinical manifestations (especially neurological signs) there was no relevant difference in the efficacy of oral or IM vitamin B12 administration [21,22,24]. Nevertheless, to our knowledge, the effect of oral cobalamin treatment in patients presenting with severe neurological manifestations has not yet been adequately documented. Thus, until this has been studied, parenteral vitamin B12 therapy is still to be recommended for such patients [26].
To our knowledge, 2 of the aforementioned studies reported data on adverse events, with 2 of such adverse events in one study in the group of oral vitamins B12 [21,22].

\section{Systematic reviews of oral vitamin B12 therapy in vita- min B12 deficiency}

The first evidence-based analysis by the Vitamin B12 Cochrane Group in 2005 supports the efficacy of oral vitamin B12 as a curative treatment, with a dose between 1,000 and 2,000 $\mu \mathrm{g}$ ( 1 and $2 \mathrm{mg}$ ) initially prescribed daily and then weekly [27]. This structured-analysis includes patients with Biermer's disease. In this analysis, serum vitamin B12 levels increased significantly in patients receiving oral vitamin B12 and both groups of patients (receiving oral and IM treatment) showed an improvement in neurological symptoms. The Cochrane Group concludes that daily oral therapy may be as effective as IM administration in obtaining short term hematological and neurological responses in vitamin B12 deficient patients [27].

The recent evidence based-analysis from the same group in 2018, also including the context of Biermer's disease, confirms their previous analysis [23]. In fact, the Cochrane Group concludes that: "there is evidence of low quality that oral vitamin $B 12$ or vitamin $B 12$ administered intramuscularly have similar effects in normalizing vitamin B12 serum levels, but oral treatment costs less. Further trials should conduct better randomization and blinding procedures, recruit more participants, and provide adequate reporting. Future trials should also measure important outcomes such as the clinical signs and symptoms of vitamin B12 deficiency, health related-quality of life, socioeconomic effects, and report adverse events adequately".

\section{Prospective studies of oral vitamin B12 therapy in pa- tients with Biermer's disease}

Our working CARE B12 group has developed an effective oral curative treatment for patients presenting with FCM and pernicious anemia using crystalline cyanocobalamin [28-32]. This treatment has been validated through several studies on small numbers of patients with a well-documented vitamin B12 deficiency, this latter of welldefined etiology. In the majority of studies, the effectiveness of treatment has been validated on the correction of serum vitamin B12 levels and that of hematological abnormalities, in general at 3 months (short term efficacy) [28-32]. In some studies, correction of neurological signs or clinical manifestations has also been sought. In all the studies, adverse events were studied. 
Analysis of these data from the studies conducted by the CARE $B 12$ group confirms the previously reported efficacy of oral crystalline cyanocobalamin, particularly in FCM and in elderly patients [28-31]. All of the patients who were treated orally corrected their vitamin B12 levels and at least two-thirds corrected their hematological abnormalities. Moreover, one-third of patients experienced a clinical improvement on oral treatment. In most cases of FCM a low vitamin B12 dose (i.e. $125-1,000 \mu \mathrm{g}$ [0.125 to $1 \mathrm{mg}$ ] of oral crystalline cyanocobalamin per day) was used.

The aforementioned results were also observed in a population of patients presenting with Biermer's disease (Table 3) [33]. In this setting, the CARE B12 group studied in an open study 10 patients with welldocumented vitamin B12 deficiency related to pernicious anemia who daily received $1,000 \mu \mathrm{g}(1 \mathrm{mg})$ of oral crystalline cyanocobalamin for at least 3 months [32]. After 3 months of treatment, serum vitamin B12 levels were increased in all 9 patients in whom it was measured (mean increase of $117.4 \mathrm{pg} / \mathrm{mL} ; p<0.0000003$ compared with baseline). Eight patients had increased hemoglobin levels (mean increase of 2.45 $\mathrm{g} / \mathrm{dL} ; p<0.01)$. All 10 patients had decreased mean erythrocyte cell volume (mean decrease of $10.4 \mathrm{fL} ; p<0.003$ ). Three patients (one-third) experienced clinical improvements.

Two other studies have documented the efficacy of oral vitamin B12 therapy in patients with pernicious anemia (Table 3) [20,34]. These studies also had small sample size but had longer follow-up period (up to 18 months).

Oral vitamin B12 was effective in all the patients (10 patients had Biermer's disaese) in Nyholm's study $(\mathrm{n}=40)$ with the median serum vitamin B12 level of $1,193 \mathrm{pg} / \mathrm{mL}$ after 3 months of treatment (Table 3) [20]. It was also reported that using oral treatment did not result in any new neurological complications.

Normalization of serum vitamin B12 levels was seen in all patients (inclusive of patients with pernicious anemia) in Delpre's study with oral (sublingual) vitamin B12 replacement $(n=18)$ (Table 3) [34]. An increase in vitamin B12 level was as much as fourfold compared with pretreatment in most patients. The mean change of $387.7 \mathrm{pg} / \mathrm{mL}$ was significant $(p=0.0001)$.

The CARE B12 group had also documented the long-term efficacy of oral vitamin B12 treatment, with a median follow up of 2.5 years, in a population of 22 patients including patients with pernicious anemia
[35]. These preliminary findings are in accordance with the results of Roth's study, with a median follow up of more than 4 years on oral vitamin B12 therapy [36].

The CARE B12 group also documented in a small study (10 patients) the relative efficacy of oral cyanocobalamin treatment on cognitive functions (Mini Mental State Examination score) [37].

In these studies, including 132 patients [28-32], only 2 of these (1.5\%) reported treatment-related adverse events such as skin allergy.

\section{Experience of oral vitamin B12 therapy in patients with Biermer's disease in a reference center}

Thus, since the 2000's, at least half of the patients followed in the Hôpitaux Universitaires de Strasbourg (University Hospital of Strasbourg, Strasbourg, France) with well-documented vitamin B12 deficiency were treated with oral cyanocobalamin, with a dose between 125 and $2,000 \mu \mathrm{g}$ ( 0.125 to $2 \mathrm{mg}$ ) per day depending on whether the cause is Biermer's disease or FCM (Table 4 for the used scheme) [26]. In the Department of Internal Medicine in the aforementioned Institution ( $>800$ patients with a documented cobalamin deficiency, median age 71 years), FCM accounts for about $60-70 \%$ of the cases of vitamin B12 deficiency in elderly patients, whereas Biermer's disease accounted for only $15-25 \%$ [38]. All of these patients who were treated orally corrected their vitamin B12 levels and at least $80 \%$ corrected their hematological abnormalities [26]. Moreover, half of the patients experienced a clinical improvement on oral treatment. It is to note that the patients presenting with severe neurological manifestations were usually excluded by our team for the oral vitamin B12 treatment. In the experience of the CARE $B 12$ group, oral vitamin B12 treatment avoids the discomfort, inconvenience and cost of monthly injections.

\section{Perspectives and direction of future research}

To date the oral vitamin B12 treatment regimen not yet formally approved [3]. Further studies should include testing the efficacy of different molecules (cyano-, hydroxo-, methyl-cobalamin) and dosages. It may be important to study the knowledge and practices of doctors/health-care workers with regard to oral replacement therapy with vitamin B12 for patients with cobalamin deficiency.

Recent developments in conjunction with nanomedicine for the co-administration of drugs with lipid compounds have been reported

Table 3. Studies of oral vitamin B12 treatment in patients with Biermer's disease [20,32,34,35]

\begin{tabular}{|c|c|c|}
\hline Study characteristics (number of patients) & Therapeutic modalities & Results \\
\hline $\begin{array}{l}\text { Prospective, case series of low vitamin B12 levels }(n=40) \text {, } \\
\text { including } 10 \text { patients with Biermer's disease } \\
{[20]}\end{array}$ & $\begin{array}{l}\text { Loading dose of IM vitamin B12 till vitamin } \\
\text { B12 level reached lower } 25 \text { th centile }(418 \mathrm{pg} / \mathrm{mL}) \text { and then } \\
\text { converted to oral vitamin B12 } 1000 \mu \mathrm{g}(1 \mathrm{mg}) \text { per } \text { day, during } \\
3-18 \text { months }\end{array}$ & $\begin{array}{l}\text { Normalization of the serum vitamin B12 levels in all patients. } \\
\text { At } 3 \text { months, median serum vitamin B12 level of } 1193 \mathrm{pg} / \mathrm{mL} \\
\text { No adverse-effect }\end{array}$ \\
\hline $\begin{array}{l}\text { Open prospective study of low vitamin B12 levels related to } \\
\text { Biermer's disease }(\mathrm{n}=10) \\
{[32]}\end{array}$ & $\begin{array}{l}\text { Oral crystalline cyanocobalamin: } 1,000 \mu \mathrm{g}(1 \mathrm{mg}) \text { per day, } \\
\text { during at least } 3 \text { months }\end{array}$ & $\begin{array}{l}\text { Significant increase of serum vitamin B12 levels in } 90 \% \text { of } \\
\text { the patients (mean of } 117.4 \mathrm{pg} / \mathrm{mL} \\
\text { Significant increase of Hb levels (mean of } 2.45 \mathrm{~g} / \mathrm{dL} \text { ) and } \\
\text { decrease of ECV (mean of } 10.4 \mathrm{fL} \text { ) } \\
\text { Improvement of clinical abnormalities in } 30 \% \text { of the patients } \\
\text { No adverse-effect }\end{array}$ \\
\hline $\begin{array}{l}\text { Open prospective study of low vitamin B12 levels related to } \\
\text { Biermer's disease }(\mathrm{n}=18) \\
{[34]}\end{array}$ & Sublingual cobalamin for 7-12 days & $\begin{array}{l}\text { Normalization of serum vitamin B12 levels. Significant mean } \\
\text { changes of } 387.7 \mathrm{pg} / \mathrm{mL}(p=0.0001) \\
\text { Increase in vitamin B12 level as much as fourfold compared } \\
\text { with pretreatment in most patients }\end{array}$ \\
\hline $\begin{array}{l}\text { Cohort study of low vitamin B12 levels ( } \mathrm{n}=22) \text {, including } \\
\text { patients with Biermer's disease [35] }\end{array}$ & $\begin{array}{l}\text { Oral crystalline cyanocobalamin: } 650 \mu \mathrm{g}(0.65 \mathrm{mg}) \text { per day, } \\
\text { during a median of } 2.5 \text { years }\end{array}$ & $\begin{array}{l}\text { Normalization of serum vitamin B12 levels in } 95 \% \text { of the } \\
\text { patients } \\
\text { Significant increase of } \mathrm{Hb} \text { levels (mean of } 1.1 \mathrm{~g} / \mathrm{dL} \text { ) } \\
\text { Improvement of clinical abnormalities in } 20 \% \text { of the patients } \\
\text { No adverse-effect }\end{array}$ \\
\hline
\end{tabular}

Hb: Hemoglobin; ECV: Erythrocyte cell volume; MMSE: Mini mental state examination 
Table 4. Recommendations for oral vitamin B12 treatment $[23,26]$

\begin{tabular}{|c|c|c|}
\hline & Biermer's disease & Intake deficiency and food-cobalamin malabsorption \\
\hline Parenteral administration (intramuscular) & $\begin{array}{l}\text { Cyanocobalamin: } \\
-1,000 \mu \mathrm{g}(1 \mathrm{mg}) \text { per } \text { day for } 1 \text { week } \\
\text { - than } 1,000 \mu \mathrm{g}(1 \mathrm{mg}) \text { per week for } 1 \text { month } \\
\text { - than } 1,000 \mu \mathrm{g}(1 \mathrm{mg}) \text { per } \text { each month, for life } \\
(1,000 \text { to } 2,000 \mu \mathrm{g}[1 \text { to } 2 \mathrm{mg}] \text { per } \text { day for at least } 1 \text { to } 3 \text { months } \\
\text { in case of severe neurological manifestations })\end{array}$ & $\begin{array}{l}\text { Cyanocobalamin: } \\
\text { - } 1,000 \mu \mathrm{g} \text { per }(1 \mathrm{mg}) \text { day for } 1 \text { week } \\
\text { - than } 1,000 \mu \mathrm{g}(1 \mathrm{mg}) \text { per week for } 1 \text { month } \\
\text { - than } 1,000 \mu \mathrm{g}(1 \mathrm{mg}) \text { per } \text { each } 1 \text { or } 3 \text { months, until the } \\
\text { cobalamin deficiency cause is corrected } \\
(1,000 \mu \mathrm{g}[1 \mathrm{mg}] \text { per } \text { day for at least } 1 \text { to } 3 \text { months in case of } \\
\text { severe neurological manifestations })\end{array}$ \\
\hline Oral administration & $\begin{array}{l}\text { Cyanocobalamin: } \\
1,000 \mu \mathrm{g}(1 \mathrm{mg}) \text { per day for life* }\end{array}$ & $\begin{array}{l}\text { Cyanocobalamin: } \\
-1,000 \mu \mathrm{g}(1 \mathrm{mg}) \text { per day for } 1 \mathrm{month} \\
\text { - than } 125 \text { to } 1,000 \mu \mathrm{g}(0.125 \text { to } 1 \mathrm{mg}) \text { per day, until the } \\
\text { cobalamin deficiency cause is corrected* }\end{array}$ \\
\hline
\end{tabular}

"The effect of oral cobalamin treatment in patients presenting with severe neurological manifestations has not yet been adequately documented.

to enhance lymphatic transport. These technologies have been recently used to administrate vitamin B12 [39].

Nasal and sublingual administrations of vitamin B12 (placing the vitamin beneath the tongue for one to two minutes) are another promising way of administration that are studied [14,34].

\section{Conclusions and recommendations}

To date in worldwide clinical practice, the majority of patients with vitamin B12 deficiency is treated with parenteral vitamin B12 administration. In fact, several studies in 2000s have documented that lifelong IM injection for replacement is still a common and usual practice. Nevertheless, as early as the 1950 s, there were studies suggesting that oral vitamin B12 replacement may provide adequate absorption. Nevertheless, oral vitamin B12 replacement in patients with vitamin B12 remains uncommon in clinical practice. In this setting, oral cobalamin remains the "best keep secret in medicine" [40]. In our opinion, it may be "time to communicate on this treatment possibility" and "time to propose international recommendations" [41].

The present analysis and the experience of the CARE B12 group support the use of oral vitamin B12 replacement in clinical practice. Considering the present work, we can recommend a dose of 1,000 $\mu \mathrm{g}(1 \mathrm{mg})$ per day of oral cyanocobalamin for life in case of Biermer's disease (Table 4) $[23,26]$. In case of intake deficiency or food-cobalamin malabsorption, we can recommend $1,000 \mu \mathrm{g}(1 \mathrm{mg})$ per day of oral cyanocobalamin for 1 month and then 125 to $1,000 \mu \mathrm{g}$ ( 0.125 to 1 $\mathrm{mg}$ ) per day, until the cobalamin deficiency cause is corrected. In this setting, the following can also be proposed: ongoing supplementation is needed until any associated disorders are corrected (e.g. by halting the ingestion of the offending medication or exogenesis, or by treating Helicobacter pylori infection or pancreatic exocrine failure) $[9,26]$. This may result in lifelong administration or, when applicable, sequential administration.

The effect of oral vitamin B12 treatment in patients presenting with severe neurological manifestations (e.g. combined sclerosis) has not yet been adequately documented $[23,26]$. Thus, such patients with should be treated with IM replacement, to favor rapid replenishment of vitamin B12 stores and to avoid irreversible consequences of the vitamin deficiency. After major regression of the manifestation, patients may be able to be treated with oral vitamin B12 replacement (required a close monitoring).

In clinical practice, one of the predominant elements for the choice of treatment options is the patient preference $[26,42]$. This latter should absolutely be taken into consideration. Other factors of this choice (IM vs. oral) include patient compliance and patient comorbidities. Thus, in patients with non-compliance to oral vitamin B12 treatment,
IM vitamin replacement may be a better option. In patients, whereby IM injections are contraindicated because of coagulopathy or the use anti-coagulation and/or anti-platelet medication, oral replacement is the best option. In this setting, oral replacement will also be interest to avoid painful and administration difficulties.

\section{Funding}

Our research on vitamin B12 deficiency was supported by a grant from the Fondation de France (Prix Robert et Jacqueline Zittoun 2004).

\section{Competing interests}

The authors have no conflicts of interest that are directly relevant to the content of this manuscript.

\section{Authors contribution}

Conceived and designed the study: EA and AAZ. Performed the study: EA, AAZ and TV. Analyzed the data: EA and AAZ. Interpreted the results: EA and AAZ. Wrote the paper: EA and AAZ. Principal Investigator of this study and supervised this study: EA. Revised the paper critically and give final approval for publication: all authors.

\section{References}

1. Herrmann W, Obeid R (2012) Cobalamin deficiency. Subcell Biochem 56: 301-322. [Crossref]

2. Dali-Youcef N, Andrès E (2009) An update on cobalamin deficiency in adults. QJM 102: 17-28. [Crossref]

3. Lane LA, Rojas-Fernandez C (2002) Treatment of vitamin b(12)-deficiency anemia: oral versus parenteral therapy. Ann Pharmacother 36: 1268-1272. [Crossref]

4. Hvas AM, Nexo E (2006) Diagnosis and treatment of vitamin B12 deficiency--an update. Haematologica 91: 1506-1512. [Crossref]

5. Andrès E, Loukili NH, Noel E, Kaltenbach G, Abdelgheni MB, et al. (2004) Vitamin B12 (cobalamin) deficiency in elderly patients. CMAJ 171: 251-259. [Crossref]

6. Green R, Allen LH, Bjørke-Monsen AL, Brito A, Guéant JL, et al. (2017) Vitamin B12 deficiency. Nat Rev Dis Primers 3: 17040. [Crossref]

7. Chatthanawaree W (2011) Biomarkers of cobalamin (vitamin B12) deficiency and its application. J Nutr Health Aging 15: 227-231. [Crossref]

8. Carmel R (1995) Malabsorption of food cobalamin. Baillieres Clin Haematol 8: 639655. [Crossref]

9. Andrès E, Affenberger S, Vinzio S, Kurtz JE, Noel E, et al. (2005) Food-cobalamin malabsorption in elderly patients: clinical manifestations and treatment. Am J Med 118 : 1154-1159. [Crossref]

10. Andrès E, Dali-Youcef N, Vogel T, Serraj K, Zimmer J (2009) Oral cobalamin (vitamin $\mathrm{B}(12))$ treatment. An update. Int J Lab Hematol 31: 1-8. [Crossref]

11. Lee GR (1999) Pernicious anemia and other causes of vitamin B12 (cobalamin) deficiency. In: Lee GR, et al., eds. Wintrobe's Clinical Hematology. 10th ed. Baltimore: Williams \& Wilkins, pp: 941-964. 
12. Arendt J, Nexø E (2011) Treatment response in vitamin B12 deficiency depends on the chosen vitamin B12 preparation. Ugeskr Laeger 173: 2634-2635. [Crossref]

13. Elia M (1998) Oral or parenteral therapy for B12 deficiency. Lancet 352: 1721-1722. [Crossref]

14. Slot WB, Merkus FW, Van Deventer SJ, Tytgat GN (1997) Normalization of plasma vitamin B12 concentration by intranasal hydroxocobalamin in vitamin B12-deficient patients. Gastroenterology 113: 430-433. [Crossref]

15. van Asselt DZ, Merkus FW, Russel FG, Hoefnagels WH (1998) Nasal absorption of hydroxocobalamin in healthy elderly adults. Br J Clin Pharmacol 45: 83-86. [Crossref]

16. Masucci L, Goeree R (2013) Vitamin B12 intramuscular injections versus oral supplements: a budget impact analysis. Ont Health Technol Assess Ser 13: 1-24. [Crossref]

17. Castelli MC, Friedman K, Sherry J, Brazzillo K, Genoble L, et al. (2011) Comparing the efficacy and tolerability of a new daily oral vitamin B12 formulation and intermittent intramuscular vitamin B12 in normalizing low cobalamin levels: a randomized, openlabel, parallel-group study. Clin Ther 33: 358-371. [Crossref]

18. Lin J, Kelsberg G, Safranek S (2012) Clinical inquiry: Is high-dose oral B12 a safe and effective alternative to a B12 injection? J Fam Pract 61: 162-163. [Crossref]

19. Butler CC, Vidal-Alaball J, Cannings-John R, McCaddon A, Hood K, et al. (2006) Oral vitamin B12 versus intramuscular vitamin B12 for vitamin B12 deficiency: a systematic review of randomized controlled trials. Fam Pract 23: 279-285. [Crossref]

20. Nyholm E, Turpin P, Swain D, Cunningham B, Daly S, et al. (2003) Oral vitamin B12 can change our practice. Postgrad Med J 79: 218-220. [Crossref]

21. Kuzminski AM, Del Giacco EJ, Allen RH, Stabler SP, Lindenbaum J (1998) Effective treatment of cobalamin deficiency with oral cobalamin. Blood 92: 1191-1198. [Crossref]

22. Bolaman Z, Kadikoylu G, Yukselen V, Yavasoglu I, Barutca S, et al. (2003) Ora versus intramuscular cobalamin treatment in megaloblastic anemia: a single-center, prospective, randomized, open-label study. Clin Ther 25: 3124-3134. [Crossref]

23. Wang H, Li L, Qin LL, Song Y, Vidal-Alaball J, et al. (2018) Oral vitamin B12 versus intramuscular vitamin B12 for vitamin B12 deficiency. Cochrane Database Syst Rev 3: CD004655. [Crossref]

24. Eussen SJ, de Groot LC, Clarke R, Schneede J, Ueland PM, et al. (2005) Oral cyanocobalamin supplementation in older people with vitamin B12 deficiency: a dosefinding trial. Arch Intern Med 165: 1167-1172. [Crossref]

25. Sanz-Cuesta T, González-Escobar P, Riesgo-Fuertes R, Garrido-Elustondo S, del CuraGonzález I, et al. (2012) Oral versus intramuscular administration of vitamin B12 for the treatment of patients with vitamin B12 deficiency: a pragmatic, randomised, multicentre, non-inferiority clinical trial undertaken in the primary healthcare setting (Project OB12). BMC Public Health 12: 394. [Crossref]

26. Andrès E, Fothergill H, Mecili M (2010) Efficacy of oral cobalamin (vitamin B12) therapy. Expert Opin Pharmacother 11: 249-256. [Crossref]
27. Vidal-Alaball J, Butler CC, Cannings-John R, Goringe A, Hood K, et al. (2005) Oral vitamin B12 versus intramuscular vitamin B12 for vitamin B12 deficiency. Cochrane Database Syst Rev 20: CD004655. [Crossref]

28. Andrès E, Kurtz JE, Perrin AE, Maloisel F, Demangeat C, et al. (2001) Oral cobalamin therapy for the treatment of patients with food-cobalamin malabsorption. Am J Med 111: 126-129. [Crossref]

29. Andrès E, Kaltenbach G, Noel E, Noblet-Dick M, Perrin AE, et al. (2003) Efficacy of short-term oral cobalamin therapy for the treatment of cobalamin deficiencies related to food-cobalamin malabsorption. A study of 30 patients. Clin Lab Haematol 25: 161166. [Crossref]

30. Kaltenbach G, Noblet-Dick M, Andrès E, Barnier-Figue G, Noel E, et al. (2003) Early response to oral cobalamin therapy in older patients with vitamin B12 deficiency. Ann Med Interne (Paris) 154: 91-95. [Crossref]

31. Andrès E, Kaltenbach G, Noblet-Dick M, Noel E, Vinzio S, et al. (2006) Hematologica response to short-term oral cyanocobalamin therapy for the treatment of cobalamin deficiencies in elderly patients. J Nutr Health Aging 10: 3-6. [Crossref]

32. Andrès E, Henoun Loukili N, Noel E, Maloisel F, Vinzio S, et al. (2005) Effects of oral crystalline cyanocobalamin $1000 \hat{\mathrm{I}}^{1} / 4 \mathrm{~g} / \mathrm{d}$ in the treatment of pernicious anemia: An openlabel, prospective study in Ten Patients. Curr Ther Res Clin Exp 66: 13-22. [Crossref]

33. Andrès E (2017) Oral Cobalamin Therapy for the Patient with Biermer's Disease. $J$ Blood Disord Transfus 8: 1 .

34. Delpre G, Stark P, Niv Y (1999) Sublingual therapy for cobalamin deficiency as an alternative to oral and parenteral cobalamin supplementation. Lancet 354: 740-741. [Crossref]

35. Andrès E, Serraj K, Federici L, Grosu D, BlicklÃ JF. EfficacitÃ (2007) au long cours dât ${ }^{\mathrm{TM}}$ un traitement par cyanocobalamine administrÃ $\mathcal{C}$ e par voie orale dans le cadre des carences en vitamine B12: ÃCtude de 22 cas. Rev Med Interne 28: 49.

36. Roth M, Orija I (2004) Oral vitamin B12 therapy in vitamin B12 deficiency. Am J Med 116: 358. [Crossref]

37. Jehl C, Vogel T, Andrès E, Kaltenbach G (2009) Benefits of oral cobalamin on cognitive function in elderly persons with vitamin B12 deficiency. Geriatrics World Congress, Paris, June 2009.

38. Andrès E, Goichot B, Schlienger JL (2000) Food cobalamin malabsorption: a usua cause of vitamin B12 deficiency. Arch Intern Med 160: 2061-2062. [Crossref]

39. Vitetta L, Zhou J, Manuel R, Dal Forno S, Hall S, et al. (2018) Route and type of formulation administered influences the absorption and disposition of vitamin B12 levels in serum. J Funct Biomater 12: 1-9.

40. Graham ID, Jette N, Tetroe J, Robinson N, Milne S, et al. (2007) Oral cobalamin remains medicine's best kept secret. Arch Gerontol Geriatr 44: 49-59. [Crossref]

41. Andrès E (2012) Oral cobalamin therapy: it may be perhaps time to propose international recommendations? Presse Med 41: 895-898. [Crossref]

42. Chan CQ, Low LL, Lee KH (2016) Oral Vitamin B12 Replacement for the Treatment of Pernicious Anemia. Front Med (Lausanne) 3: 38. [Crossref]

Copyright: (C2018 Andrès E. This is an open-access article distributed under the terms of the Creative Commons Attribution License, which permits unrestricted use, distribution, and reproduction in any medium, provided the original author and source are credited. 